\title{
Post-Brexit Britain and the pay culture: challenges and opportunities
}

\author{
Dr Demetra Arsalidou
}

\author{
Senior Lecturer, School of Law and Politics, Cardiff University \\ Dr Alison LuI
}

Senior Lecturer, Liverpool John Moores University

\begin{abstract}
This paper examines the impact of Brexit on financial services regulation in relation to three areas linked to executive remuneration. They are: the bonus cap; the clawback of pay; and the level of disclosure required by shareholders with regard to details of directors' remuneration. It will be argued that legally Brexit will have little impact on any of the three areas. UK legislation has already incorporated a great deal of EU legislation. The status quo of retaining such legal restrictions seems sensible in light of public sentiment towards unfairness in executive compensation and uncertainty towards the Brexit negotiations. Nevertheless, London faces stiff competition from other major international financial centres in a post-Brexit era. The loss of single passporting rights is also encouraging major banks to invest in other European financial centres. Brexit creates opportunities too. With the integration of digital technology, it is possible to create convenient platforms where investors can access reports on executive remuneration.
\end{abstract}

Keywords: Brexit; bonus cap; clawback provision; corporate governance; disclosure requirements; executive remuneration; shareholder engagement.

\section{Introduction}

'B rexit means Brexit' was possibly the most common catchphrase of 2016. That was the year Britain voted to leave the European Union (EU). Against the Brexit backdrop, there is great uncertainty about the precise future of a number of factors within the UK financial sector. One of them is executive remuneration. The controversy over executive pay has been around for some time: for years we have been told that banks and other financial institutions over-reward their staff. We have also been told that ill-thought-out remuneration designs can lead to unfair transfers of value from companies, their shareholders and other stakeholders to executives, and they can also affect companies' longterm sustainability. ${ }^{1}$ For this reason, in order to transform the bonus and excessive pay culture of European Banks, the European Commission has adopted a number of critical measures over the past few years. ${ }^{2}$ These have proven popular on a continent struggling to

1 L Bebchuk and J Fried, 'Pay without Performance: The Unfulfilled Promise of Executive Compensation' (Harvard University Press 2004); S Thompson, 'Executive Pay and Corporate Governance Reform in the UK: What Has Been Achieved?' in R S Thomas and J G Hill (eds), Research Handbook on Executive Pay (Edward Elgar 2010).

2 Commission Recommendations 2004/913/EC, 2005/162/EC, 2009/385/EC (2013/36/EU) (CRD). <http://eurlex.europa.eu/LexUriServ/LexUriServ.do?uri=OJ:L:2009:120:0028:0031:EN:PDF>. 
emerge from the ruins of the recent and most catastrophic financial crisis. However, there is now great concern over the fate of the UK remuneration and bonus policies, particularly within the City of London; a city where the pay and bonus culture is a breeding ground for controversy and where the predominant remuneration 'ethos' is often viewed as a contributing factor for reckless and excessive risk-taking. ${ }^{3}$ The reason for the concern is this: Europe has heavily influenced the UK's domestic rules, such as the malus provisions, bonus clawback and bonus caps. In fact, the UK Remuneration Codes derive much of their current form from the European regulations. ${ }^{4}$ Topical and crucial questions therefore are: what will the UK's exit from the EU mean for the country's remuneration policies? Does the EU continue to influence the way UK-based firms remunerate their high-level employees and, if so, what would change following the public's decision to leave the EU?

It could be said that there are two sides to the same coin here.

On the one hand, in the UK's current political climate there is probably little appetite for introducing changes to the remuneration rules. There is a plethora of reasons for this. To start with, despite a succession of rules aimed at curtailing excessive rewards (particularly since the emergence of the 2008 financial crisis), there has not been a noteworthy decrease in senior executives' pay. On the contrary, pay has continued to increase despite the so-called shareholder spring of $2012 .{ }^{5}$ Furthermore, businesses have dedicated significant time and effort adjusting to new rules and legislation. There is also the need to consider the impact that drastic changes can have on the investor community: irrespective of Brexit, investors need to feel confident that they operate within a favourable investment climate; any existing rules that help enhance investor confidence will not be abandoned so hastily. Britain is not experiencing the kind of political climate that would justify deserting policies that target poor remuneration policies and designs. Progressive measures have entered EU and UK law as part of a wider overhaul of capital rules in order to help strengthen investor protection, bring more stability into the banking system and reduce risky speculation. Why would the UK government want to deviate from the existing rules and willingly agree to undergo an extensive revision of its remuneration laws and regulations?

But there is also the other side of the coin. The side that suggests that Brexit can provide the perfect opportunity for the City to shine. Industry participants would argue that Britain can benefit from freeing itself of certain EU regulations, particularly those that the City did not want in the first place. Some of the more unwelcome areas of EU regulation, such as the controversial bankers' bonus cap under the Capital Requirements Directive (CRD) IV (2013/36/EU), could be altered or scrapped altogether and Brexit could finally grant Britain the chance to expand its global footprint without the need to obey a tsunami of EU directives.

3 A Lui, 'Greed, Recklessness and/or Dishonesty? An Investigation into the Culture of five UK Banks between 2004 and 2009’ (2015) 16(2) Journal of Banking Regulation 106.

4 These are implemented in the UK through the FCA Remuneration Code, which makes recommendations on the structure of remuneration for risk-taking staff and requires aggregate disclosure of amounts paid to these staff: FCA Remuneration Code, FSA's Senior Management Arrangements, Systems and Controls (SYSC) sourcebook <https://www.handbook.fca.org.uk/handbook/SYSC/3/>.

5 According to the latest data from the High Pay Centre, Britain's top executives have continued to receive pay rises despite greater scrutiny of executive rewards. The average pay for a FTSE 100 CEO rose to $£, 5.480$ million in 2015, an increase from f,4.964 million in 2014 and significantly higher than the $f 4.129$ million in 2010. The calculation was based on the 'single figure' pay disclosure of 62 top-flight firms that have published their remuneration reports for the 2015 financial year. This 'single figure' consists of the executive salary, bonuses, long-term incentives and pensions: 'The State of Pay: High Pay Centre Briefing on Executive Pay' (2016) < http://highpaycentre.org/files/The_State_of_Pay_2015.pdf>. 
This article will focus on the possible impacts of Brexit on financial services regulation in relation to three areas linked to executive remuneration: the capping of banker's bonuses, a policy pushed forward by the Europeans as part of their most comprehensive banking reforms to date; the clawback of pay, by which money already paid is returned under certain conditions; and finally the level of disclosure required by shareholders regarding details of directors' remuneration and the extent to which shareholder approval is needed. The key question is whether these European initiatives can survive the Brexit currents or whether their 'demolition' will eventually prove unavoidable.

\section{Britain: be aware of Brexit?}

There is a firm framework in Europe regulating executive remuneration that mitigates the impact of excessive risk-taking. The EU regulators made a direct attempt to eradicate 'rewards for failure' in the financial sector through a variety of measures. Central to these is the CRD IV which is directly applicable to firms across the EU and implemented through national law and the Capital Requirements Regulation (CRR). ${ }^{6}$ The purpose of the CRD IV package is to provide a 'single rulebook' across the EU covering regulatory capital requirements, corporate governance and penalties. CRD IV brings the EU into line with the Basel III rules on banking standards, which introduce greater requirements for the quality and quantity of capital, new rules for counterparty risk, new liquidity and leverage requirements, and new macroprudential standards including a countercyclical capital buffer and capital buffers for institutions that systematically demonstrate their significance. They also contain changes to rules on corporate governance, including remuneration, and introduce a standardised EU regulatory reporting. ${ }^{7}$ According to the CRD IV, banks and investment firms must implement remuneration policies that are consistent with effective risk management. Remuneration policies must not promote risktaking that surpasses the level of accepted risk of a particular institution. In addition, a clear distinction must be drawn between the criteria for setting fixed and variable pay: fixed remuneration must be permanent, predetermined, non-discretionary and nonrevocable, whilst variable pay must depend on performance. Institutions must be in a position to explain and justify to their stakeholders the use of any variable remuneration component. These rules are binding on all EU member states and apply to all EU banks, the EU operations of foreign banks and institutions, and third-country subsidiaries of EU banks (but largely not hedge funds, which are governed by separate legislation). They give the right to national banks and financial supervisory authorities to take action against any financial institution that fails to comply and allow national supervisors to impose penalties either to restrain discovered breaches of the new rules or to remedy their causes.

Significantly, central to the directive's measures are 'malus' (the adjustment of an award of variable remuneration before it has vested), 'clawback' (the return of money already paid to employees under certain conditions), 'bonus caps' (capping the bonus payments of senior staff in financial institutions) and, last but not least, 'remuneration disclosure' (the level of disclosure required by shareholders regarding details of directors' remuneration and the extent to which shareholder approval is needed). In looking at these

$6 \quad(575 / 2013)$

7 Basel III is an overhaul of banking rules and the biggest shake-up of the banking system since the global financial crisis. Before its implementation, the lack of solid financial cushions meant that many banks were at risk, requiring taxpayer-funded bailouts to avoid collapse. Basel III focuses on a ratio of high-quality capital called tier 1, which is needed to protect it against any future shocks. The high-quality capital will increase to 9 per cent after the rules come into effect: Commission Recommendations (n 2). 
measures in more detail, unless otherwise specified, up to 100 per cent of variable pay must be subject to malus or clawback arrangements, a particularly useful tool in circumstances where the employee took part or was responsible for conduct resulting in significant losses to his/her institution or failed to adhere to the appropriate standards of fitness and propriety. In addition, bankers' bonuses are to be capped; the maximum payout is set at a year's salary, and this can increase to two years' salary with shareholder approval. ${ }^{8}$ In other words, provided two-thirds of shareholders approve, bonuses for regulated staff are capped at 200 per cent of salary; in the absence of such an agreement bonuses are capped at 100 per cent of salary. The other area of executive remuneration addressed by the EU is disclosure of directors' remuneration: a European Shareholder Rights Directive (2007/36/EC) and new EU rules extend shareholders' right to vote under the 'say-on-pay' provisions. ${ }^{\text {? }}$

Britain derives its rules on executive pay from domestic as well as EU legislation. ${ }^{10}$ Matters related to executive remuneration were first given attention in 1995 following a period of public dissatisfaction on the levels of directors' pay. The result was the Greenbury Code Directors' Remuneration, Report of a Study Group, ${ }^{11}$ which recommended establishing remuneration committees of non-executive directors to decide on levels of remuneration and on particular pay packages. The aim was to introduce an element of independence in deciding the level of the executive's pay. The report's recommendations were later incorporated into the UK Listing Rules and the UK Corporate Governance Code 2012. ${ }^{12}$ Crucially, the last few years have seen an explosion of reforms to the regulation of the UK's financial industries, including changes to remuneration and bonuses rewarded to executives of large financial institutions. These reforms were heavily influenced by the EU; it is EU initiatives that have affected the domestic requirements (such as the clawback and malus provisions) of the UK Corporate Governance Code and the Investment Association's principles of remuneration. The current UK Remuneration $\operatorname{Codes}^{13}$ derive much of their present form from European legislative packages and regulations, particularly CRD IV, and the practical details of CRD IV are set out in the revised SYSC Remuneration Code. ${ }^{14}$ Importantly, all UK banks and building societies (and some investment firms) are also subject to the requirements of CRD IV.

8 The agreement is on a mandatory 1:1 ratio on salary relative to variable pay, which can rise to 2:1 with explicit shareholder approval.

9 The new EU rules extending shareholders' right to vote under the say-on-pay provisions are to be found in Directive (EU) 2017/828 of the European Parliament and of the Council of 17 May 2017, amending Directive 2007/36/EC as regards the encouragement of long-term shareholder engagement.

10 There are currently over 100,000 items of UK legislation in the UK which have their origins in EU treaties. It is not clear whether these pieces of legislation will remain as they are, be repealed, or come to an end as a result of Brexit. What happens next is a question the UK Parliament will inevitably face in the years to come.

11 Chaired by Sir Richard Greenbury (1995).

12 UK Corporate Governance Code (2012), s D.

13 There are five Remuneration Codes in the UK tailored to different types of firm: SYSC 19A - IFPRU Remuneration Code; SYSC 19B - AIFM Remuneration Code; SYSC 19C - BIPRU Remuneration Code; SYSC 19D - Dual-regulated Firms Remuneration Code; SYSC 19E - UCITS Remuneration Code. The Codes apply to more than 3000 firms, including banks, building societies, large full-scope UK alternative investment fund managers, CRD investment firms such as broker-dealers, investment managers, corporate finance, private equity and venture capital firms, and operators of multilateral trading facilities and management companies of undertakings in collective investments in transferrable securities.

14 In recent years, we have seen the implementation of CRD III and IV, AIFMD, UCITSv and Solvency II, all of which encompass regulation linked to remuneration. These rules that have already been implemented in UK regulation. 
And yet, the future of many of the aforementioned areas remains uncertain following Brexit. Uncertainty is not a welcome prospect; the health of the UK economy largely depends on the design of its financial services industry, an industry that accounts for approximately 8 per cent of UK gross domestic product (GDP). In this regard, in the short-to-medium term nothing will change. Still, what happens next matters greatly. Following the country's notice of its exit, a transitional period will follow, during which the UK's future relationship with the EU will be negotiated. Where EU law has been incorporated into primary UK legislation no change will happen. But under the terms of the European Communities Act 1972, EU law can take the form of secondary legislation; such secondary legislation can fall away unless deliberately retained. According to a detailed briefing published by the House of Commons Library concerning the process for the UK leaving the EU, there are provisions of the CRD IV that do not derive from Basel III proposals, but rather from the EU's own policy; amongst these are those relating to corporate governance and remuneration. Upon Brexit, the UK will be free to rid itself of any unwanted provisions without deviating from the Basel III requirements. This means that the aforesaid European-inspired steps, solid as they are, might not survive the Brexit currents; some parts of EU regulation could be altered or scrapped altogether.

The following section will examine three key areas of the UK corporate governance framework that are derived directly from EU initiatives - namely, clawback, caps on bonuses and remuneration disclosure - and will consider whether their post-Brexit 'evaporation' is at all likely. ${ }^{15}$

\subsection{BREXIT AND ITS IMPACT ON 'CLAWBACK'}

A clawback provision is a special contractual clause by which money already paid to employees must be paid back under certain conditions. Put simply, clawback makes someone give something back. In the employment context, it is triggered when an employer claims repayment of remuneration which has already been paid to an employee upon the happening of specified circumstances. In practice, this normally relates to the repayment of cash, stock or other assets already awarded to an employee. An invaluable tool, it permits firms to instruct executives to return their bonuses under the presence of certain conditions. Bonuses are normally given annually in cash, and frequently in the City of London big parts of bonuses are paid under a different type of arrangement, commonly referred to as the 'deferred incentive plan'. It is these deferred incentive plans that, in practice, are being clawed back. What this means is that performance is measured over a period of time with the bonus being delayed accordingly, thereby granting the employee an incentive to perform well within a specific role. Where a bonus is paid on the basis of performance which subsequently turns out to have been miscalculated, it can be clawed back. This happened recently when directors of Lloyds Bank were asked to return large parts of their bonuses as a result of the bank's decision to pay compensation

15 For an excellent discussion on the remuneration policies in the EU, see Ellis Ferran, 'Crisis-driven Regulatory Reform: Where in the World is the EU Going?’ in E Ferran, N Moloney, J G Hill and J C Coffee Jr (eds), The Regulatory Aftermath of the Global Financial Crisis (Cambridge University Press 2012); Guido Ferrarini and Niamh Moloney, 'Executive Remuneration in the EU: The Context for Reform' (2005) 21 Oxford Review of Economic Policy 304; For an in-depth evaluation, see T Boeri, C Lucifora and K J Murphy (eds), Executive Remuneration and Employee Performance-Related Pay: A Transatlantic Perspective (Oxford University Press 2013 ) 92. For a more general discussion, see Jaap Winter, 'Corporate Governance Going Astray: Executive Remuneration Built to Fail' in Thomas and Hill (n 1); D Arsalidou, Rethinking Corporate Governance in Financial Institutions (Routledge 2015). For a thorough discussion of executive remuneration in the UK and its theoretical underpinnings, see M Petrin, 'Executive Compensation in the United Kingdom - Past, Present, and Future' (2015) 36(7) The Company Lawyer 196; D Arsalidou, 'The Regulation of Executive Pay and Economic Theory (2011) 5 Journal of Business Law 431. 
in excess of $f^{3.2}$ billion to customers who were wrongly sold payment protection insurance. ${ }^{16}$

In the revised UK Corporate Governance Code of 2014, a significant amendment was introduced by the Financial Reporting Council (FRC): firms are now required to include provisions enabling performance adjustment or post-vesting clawback for the variable pay of executive directors (including bonuses and long-term incentives). Firms must also include details of the exact circumstances that entitle remuneration committees to act, should they deem necessary. This differs greatly from the wording used in the previous Corporate Governance Code that granted remuneration committees the power to act 'in exceptional circumstances of misstatement or misconduct'. Now, it is up to individual companies to determine the circumstances that would justify interference by their remuneration committees. As a consequence, many companies will need to strengthen their policies. Even though the majority of companies already have measures in place concerning the clawback of pay under specified conditions, not many include provisions regarding the clawing back of payments already granted. With the toughening-up of the clawback rules, firms are required to define their policies in relation to issues such as the precise circumstances that would provoke clawback, the time limit of the clawback risk and the design of variable deferred pay (that should ensure that sums are withheld or recovered). Crucially also, the Prudential Regulatory Authority (PRA) has recently issued a final policy statement on bonus clawback, together with an instrument making various changes to the Remuneration Code. With effect from 1 January 2015, PRA-authorised firms are required to amend their employment contracts to ensure that bonuses which have already been paid to their employees can be clawed back where necessary. ${ }^{17}$ In particular, they are required to clawback bonuses where there is evidence of employee misbehaviour, where the firm or relevant business unit suffers a material downturn in its financial performance, or where the firm or relevant business unit suffers a material failure of risk management. In addition, firms must set the specific criteria for the application of malus and clawback and must also ensure that the criteria for the application of malus and clawback include instances where the employee took part in or was responsible for conduct which resulted in significant losses to the firm, or behaved in a way which failed to meet the appropriate standards of fitness and propriety. ${ }^{18}$

There remain a number of pending questions, particularly in relation to the scope and enforceability of clawback provisions. In addition, there are outstanding technical matters, such as how non-cash bonus awards are valued or whether clawback applies to the gross or net value of bonus awards. There are a number of sensitive issues too, such as which firms should be entitled to retrieve bonuses, as well as some controversial questions, such as the exact circumstances that should entitle firms to retrieve vested and paid bonuses, especially in relation to those granted seven to ten years earlier.

16 Attracta Mooney, 'UK Fund Executives' Pay Slashed: Brexit, Fund Outflows and Declining Profitability Put Pressure on Remuneration in 2016' Financial Times (London, 9 April 2017) 8.

17 The PRA, created as a part of the Bank of England by the Financial Services Act (2012), is responsible for the prudential regulation and supervision of around 1700 banks, building societies, credit unions, insurers and major investment firms. The objectives of the PRA are set out in the Financial Services and Markets Act 2000. It has three statutory objectives:

1. a general objective to promote the safety and soundness of the firms it regulates;

2. an objective specific to insurance firms, to contribute to the securing of an appropriate degree of protection for those who are or may become insurance policyholders; and

3. a secondary objective to facilitate effective competition.

18 PRA, r 15.21. 
Unsurprisingly, there has been some opposition to use of clawback as an effective governance tool; for instance, the British Bankers' Association challenged this practice primarily on the grounds that it is unfair and potentially unenforceable. It suggested that introducing changes to employment contracts retrospectively, violates employment law in countries where UK banks function and operate. It also claimed that such a policy can destroy results-based pay, causing an increase in the overall pay awarded to executive directors. ${ }^{19}$

Still, there has not been much opposition to clawback, especially compared to numerous other corporate governance measures and initiatives. In fact, despite the controversies and outstanding technical questions, clawback provisions are now well embedded within the UK corporate governance ethos; the UK Corporate Governance Code firmly incorporates the requirement for malus and clawback in relation to executive variable pay (particularly bonuses and share plans) for all UK listed companies. Crucially, there is a high compliance level with the principles of the Code, and within this high level clawback clearly stands out. According to a 2017 survey examining the compliance of UK-based banks with the corporate governance principles, the majority of FTSE 350 firms have implemented a rule that companies must adopt the necessary arrangements to permit them to recover or withhold variable pay. The figures paint a positive picture here: 91 per cent have already adopted a clawback provision that is linked to the annual bonuses awarded to executives, and 78 per cent have adopted a clawback provision linked to their long-term plans. ${ }^{20}$

All in all, amongst the many measures adopted by the FRC to transform the bonus and excessive pay culture of the UK, clawback plays a crucial part. ${ }^{21} \mathrm{In}$ fact, there is clear enthusiasm to improve and move forward with this provision, as shown by the fact that the Financial Conduct Authority (FCA), in a bid to combat misconduct, is considering mirroring the PRA's clawback scheme with respect to FCA-regulated firms and also extending clawback to bankers' basic salaries (as opposed to solely bonuses). ${ }^{22}$ Designed properly, this practice can act as an imperative device for corporate accountability. The appetite here is for strengthening rather than weeding out the clawback provision. ${ }^{23}$

19 'BBA response to Prudential Regulation Authority Consultation on Clawback CP6/14' $<$ www.BritishBankers'Association+clawback>.

20 Corporate Governance Review <www.grantthornton.co.uk/globalassets/1.-member-firms/unitedkingdom/pdf/publication/corporate-governance-review-2017.pdf $>$. The review includes a comprehensive analysis of annual reports of the companies in the FTSE 350 and covers 305 out of 350 FTSE companies. Amongst other matters, it assesses compliance with the disclosure requirements of the UK Corporate Governance Code 2016 (and 2014 where applicable), considers the quality and detail of explanations, and draws attention to best practice and emerging trends in narrative reporting.

21 Others would include boardroom diversity and the disclosure of long-term viability statements.

22 As Wheatley explains, this is primarily because there is a tendency for employers to pay their employees higher basic salaries - a direct consequence of the CRD IV bonus cap. PRA-authorised firms must now ensure that bonuses are subject to clawback for a period of up to seven years after vesting. However, this change does not have retrospective effect: it applies only to bonuses awarded on or after 1 January 2015. Moreover, firms will not have to clawback bonuses where there is a material downturn in financial performance, but they will where either (i) there is reasonable evidence of employee misbehaviour or material error, or (ii) the firm or relevant business unit suffers a material failure of risk management: Martin Wheatley, 'FCA Issue Rules and Guidance on Bankers Remuneration and Clawback Obligations' <www.kingsleynapley.co.uk/ comment/blogs/employment-law-blog/fca-issue-rules-and-guidance-on-bankers-remuneration-andclawback-obligations> (Kingsley Napley, 10 July 2017).

23 Another indicator that there is appetite for strengthening the provisions lies in a new proposal by the FCA and PRA that firms should be entitled to extend the clawback period for senior managers for up to 10 years in the event of an internal or regulatory investigation. 


\subsection{BREXIT AND ITS IMPACT ON 'CAPS ON BONUSES'}

Perhaps the most high profile of Europe's laws and regulations is the cap on bonuses. ${ }^{24}$ Adopted in 2014, the cap limits bonuses to 100 per cent of salary, or 200 per cent with shareholder approval. This marks a momentous change; previously there was no legal pay limit on bank executives, who could earn performance bonuses many times their base salaries. The cap on bonuses is a direct result of the strong public frustration that had grown across Europe over excessive pay rewards: excessive bonuses, many endlessly argue, encourage executives to care very little about the long-term future of their institutions. ${ }^{25}$ Indeed, for many in Europe, bankers, and especially Anglo-Saxon bankers, are inherently gluttonous, careless and self-seeking. There is a general perception that there exists a system of rewards that encourages excessive risk-taking and short-sighted behaviour with little regard to the damaging effects of short-term actions. The idea therefore is that the cap can help suppress these undesirable behavioural traits; it can discourage excessive risk-taking whilst motivating executives to think carefully and prudently about the long-term prospects and profitability of their institutions.

Nevertheless, the UK banking industry has not been too supportive of the idea of imposing caps on bonuses; for instance, the head of trading at ETX Capital in London argued that, as a result of the cap, banks risk losing their top talent. ${ }^{26}$ Most crucially, the UK government made a formidable attempt to oppose its implementation; it argued that it would be relatively easy to find ways around the restrictions and that, in limiting bonuses, banks would either raise salaries or come up with alternative ways to pay their executives. ${ }^{27}$ Caps on bonuses can easily backfire, driving up fixed salaries to compensate. Firms that are not obligated to stay within the EU will be incentivised to leave and, when banks invest in future divisions, the investments will be based outside the EU. It is therefore important that any new regulation is flexible enough to permit banks to compete and prosper whilst based in the UK.

Eventually, Britain had to conform to the established position once statute passed. Notwithstanding the various challenges from London, the UK failed to garner enough support to prevent legislation on the issue. In fact, the bonus cap has been in effect since January 2014. Still, there continues to be plenty of scepticism towards this policy within the UK. This is hardly surprising; the UK hosts Europe's biggest financial services

24 For a detailed evaluation of the 'problematic' nature of the bonus cap, see $\mathrm{K}$ Asai, 'Is Capping Executive Bonuses Useful?' (Working Paper, Monetary and Capital Markets 2 WP/16/196 International Monetary Fund 2016); A Kleymenova and I Tuna, 'Regulation of Compensation' (WP 16/07 University of Chicago Booth School of Business 2017) 1. Also see 'Cap and Flayed - Europe Looks Set to Limit Bank Bonuses' The Economist (London, 23 February 2013) 13; Jane DeAnne, 'The Future of Executive Pay' Financial Times (London, 3 August 2012) 5.

25 For instance, according to a research study examining the effects of bonuses in 67 European banks, excessive financial sector bonuses caused banks to earn more in the short term but also led to unsustainable risks that eventually materialised in the financial crisis: Matthias Efing, Harald Hau, Patrick Kampkotter and Johannes Steinbrecher, 'Incentive Pay and Bank Risk-taking: Evidence from Austrian, German, and Swiss Banks' <www.eeassoc.org/doc/upload/BANK_BONUSES_ENCOURAGED_EXCESSIVE_RISK-TAKING_New_evidence_from_the_Austrian,_German_and_Swiss_financial_sectors20150822215351.pdf>.

26 As stated by Joe Rundle, the head of trading at ETX Capital in London: see 'EU Banker Bonus Cap "self defeating"' (BBC News, 28 February 2013) <www.bbc.co.uk/news/business-21621045>.

27 George Osborne, the then Chancellor of the Exchequer, lodged a complaint in the European Court of Justice in 2013, arguing that the EU banker bonus cap is misconceived but conceded defeat a year later when he abandoned the legal challenge to overturn the cap: Court of Justice of the European Union No 154/14, 20 November 2014 <https://curia.europa.eu/jcms/upload/docs/application/pdf/2014-11/cp140154en.pdf>. 
centre. ${ }^{28}$ Nevertheless, London's position is threatened by the imminent move of Morgan Stanley to Frankfurt after Brexit. Other banks, such as Goldman Sachs, Standard Chartered, Daiwa, Sumitomo Mitsui, Nomura of Japan, VTB of Russia and Woori Bank of South Korea, will be expanding their Frankfurt offices. Brussels, Dublin and Paris are also vying for a share of London's banking sector. ${ }^{29}$ The bonus restrictions could, in the long run at least, cost jobs in the City, pushing financial institutions to establish themselves in more favourable countries. A self-defeating policy such as this would see the City of London's overseas rivals exploiting this opportunity for their benefit, undermining EU support in Britain. ${ }^{30}$ Certainly, from the perspective of the cap's opponents (such as the UK banking industry and the FSA), this is a good time for Britain; the UK's exit from the EU could mean that UK-based banks can be freed from the EU's heavy and unnecessary restrictions on bonuses. Through Brexit, Britain could reinforce its position within the global financial markets, expanding its global footprint without the need to conform to unnecessary and restrictive EU rules.

The UK might decide to abandon the cap, as the case may be; this could be viewed as Britain's golden opportunity to rid itself of a measure that it has always strongly opposed. Those in financial occupations in London and elsewhere will be pleased with this prospect; many consider Brussels to be incorrigibly antagonistic to free markets, oblivious as to how accomplishment is actually attained within them. By abandoning the cap Britain will highlight the fact that there is a fine line between pleasing the crowds and chasing business out of town. ${ }^{31}$ Freedom from the cap could make Britain more competitive, particularly as against other large financial markets, such as the USA, which have not followed suit. This is evidently crucial; according to a study conducted by the Bank of England in 2015, since 2013 bonuses have climbed relatively higher in the USA than those in London. ${ }^{32}$ The study also underlines the fact that numerous large international banks, such as HSBC and Barclays, are displeased with the cap because of its application to employees more widely (provided a bank has its base in the EU). This makes it more difficult for them to employ and hold on to high-level employees in competitive cities like New York. ${ }^{33}$ There is yet another and perhaps more compelling reason here: the cap does not appear to function as originally intended. According to the aforementioned Bank of England study (interestingly conducted a year after the cap was implemented), because of the bonus cap there has been a growth in fixed remuneration as a proportion of total remuneration. In other words, the cap has resulted in bankers' salaries rising as a result of firms refusing to cut pay - at present fixed pay makes up more than 50 per cent of highlevel bankers' overall pay, up from less than 10 per cent in 2010.34 These are the unintended and most detrimental effects of the bonus cap.

28 The UK is home to approximately 78 per cent of the European capital markets and investment banking revenue. Out of this 78 per cent, 55 per cent originates from the 27 countries of the EU. The UK also holds 37 per cent of Europe's assets under management, followed by France (20\%) and Germany (10\%): see Association for Financial Markets in Europe, 'Implementing Brexit: Practical Challenges for Wholesale Banking in Adapting to the New Environment' (AFME April 2017) <www.afme.eu/globalassets/downloads/publications/afme-implementing-brexit-2017.pdf >.

29 J Rankin, 'Banks and Companies Plan Expansion in Frankfurt after Brexit' The Guardian (London, 21 July 2017) <www.theguardian.com/business/2017/jul/21/banks-and-companies-plan-expansion-in-frankfurtafter-brexit>.

30 Arsalidou, Rethinking Corporate Governance (n 15).

31 Noted by a senior investment bank executive in an interview with The Economist (n 24).

32 Bank of England Research (2015) Q4 554 <www.bankofengland.co.uk/publications/Documents/ quarterlybulletin/2015/q4.pdf>.

33 Ibid.

34 Ibid. 
Yet still, given the present political climate, the government might prefer to retain this EU measure. Even if one accepts the economic argument for scrapping the cap, the current political ambience undermines the impetus for doing so. The continued uncertainty surrounding Brexit is likely to reduce the urgency to add more ambiguity into the mix. Popular sentiment, political pressure and general appearances will matter greatly in this debate. Britain is currently susceptible to systemic uncertainty emerging from Brexit; this is not the time to appear to soften the existing regime. Rather, the government might prefer to retain its present system, a system that appears to adopt a consistent approach to pay within the European continent and that, in turn, plays its part in securing a level of confidence within the domestic and international contexts. ${ }^{35}$ In fact, the increasing public disarray over Brexit $^{36}$ might even result in remuneration levels decreasing - not because of the legal consequences of Britain leaving, but due to pressure upon industry and government to take prudent decisions within prominent and controversial fields, executive remuneration being a key one here. ${ }^{37}$ Otherwise we may see London salaries as well as bonuses rising if elements of CRD IV, the EU's banking remuneration regulations, are repealed, an alternative that the UK government would undoubtedly wish to avoid.

\subsection{BREXIT AND DISCLOSURE OF DIRECTORS' REMUNERATION}

Disclosure of information is said to address corporate governance weaknesses such as information asymmetry and promoting shareholders' voices. ${ }^{38}$ It should be made clear at this point that one of the perceived weaknesses in current corporate governance practice (i.e. the causal link between high pay disparities and company performance) is not yet proven. The hypothesis that high pay disparities harm company performance has been debated on both sides by respected academics, scholars and organisations such as the Trade Union Congress and the High Pay Centre. The first step is to analyse whether executive pay is too high. The second step is to prove the causal link between high pay disparities and company performance. The evidence for both is inconclusive to date. A range of factors can influence company performance and executive remuneration is only one of them.

In banking, profitability is even more complex with some banks operating in different jurisdictions and markets. Return on equity, the level of interest rates, bank concentration and government ownership are some of the factors that may influence banks'

35 For an interesting discussion on this issue, see: Niamh Moloney, 'The EU and Executive Pay: Managing Harmonization Risks' in 'Thomas and Hill (n 1) 466.

36 An increasing number of people think that voting to leave the EU was not a good idea, according to a new poll. The YouGov poll, conducted for The Times newspaper in 2017, shows the highest proportion of people regretting the result since the referendum in June 2016, with 47 per cent of respondents suggesting that the UK should not have voted to leave compared with 42 per cent who think it was the right decision: YouGov Poll < https://d25d2506sfb94s.cloudfront.net/cumulus_uploads/document/cbirgnop2j/YG\%20Trackers \% 20-\%20EU\%20Tracker\%20Questions_W.pdf>.

37 As noted in the Financial Times, the chief executives of Britain's largest listed fund houses saw a substantial reduction of their pay after the Brexit vote in 2016. This is possibly a result of declining profitability and investor outflows that placed significant pressure on executive pay packages. For example, in 2016 the total amount paid to the chief executives of Jupiter, Ashmore, Aberdeen, Henderson and Intermediate Capital Group decreased by between 10 and 65 per cent, as a result of significant cuts in bonuses. A strong factor contributing to this is the significant market chaos that followed the Brexit vote as well as the election of Donald Trump as US president in November 2016. This resulted in low profitability levels that were actually lower than those in 2015. Consequently, there has been a lot of pressure on pay and executive bonuses in the past year or so, pressure that is likely to go on for longer: Mooney (n 16).

38 Department for Business, Energy and Industrial Strategy Committee, Corporate Governance, Third Report of Session (HC 2016-17) ch 2. 
profitability. ${ }^{39}$ Research into the profitability of banks in the EU has only been undertaken recently. This is unusual given that the EU accounts for approximately 25 per cent of global GDP. It also has a sophisticated wholesale financial services sector, which generates over 30 per cent of the world's wholesale financial services activity. ${ }^{40}$ Earlier studies by Berg et al, ${ }^{41}$ Pastor et al, ${ }^{42}$ Lang and Welzel, ${ }^{43}$ Lozano-Vivas, ${ }^{44}$ and Dietsch and Lozano-Vivas ${ }^{45}$ focus mainly on a small range of banks in Norway, Sweden, Finland, France, Germany and Spain. Later research by Altunbas et al, ${ }^{46}$ Bikker, ${ }^{47}$ Maudos et al, ${ }^{48}$ and Schure et al ${ }^{49}$ covers a broader spectrum of EU banks.

Three recent scholarly papers ${ }^{50}$ have been cited regularly to support the argument that general executive pay is too high and unrelated to company performance. ${ }^{51} \mathrm{~A}$ critical analysis of these papers will reveal that there are limitations with these studies. The common weakness is that all three papers do not take equity incentives into account. The paper by Cooper et $\mathrm{al}^{52}$ is not about equity incentives but total pay (which includes salary and bonus). The papers by Philip ${ }^{53}$ and Florackis and Balafas ${ }^{54}$ only researched into newly granted shares and options. Yet, directors are usually incentivised by shares which have already been granted. Further, the three studies do not take into account of company size or establish the causal link. 55

In the UK, academics are inconclusive on whether executive remuneration led to distortion of incentives or whether there was too much emphasis on short-termism.

39 P Molyneux and J Thorton, 'Determinants of European Bank Profitability' (1992) 16(6) Journal of Banking and Finance 173.

40 AFME (n 28)

41 S Berg, F Forsund, L Hjalmarsson and M Suominen, 'Bank Efficiency in the Nordic Countries' (1993) 17 Journal of Banking and Finance 371.

42 J Pastor, F Perez and J Quesada, 'Efficiency Analysis in Banking Firms: An International Comparison' (Working Paper EC95-18 Instituto Valenciano de Investigaciones Economicas 1995).

43 G Lang and P Welzel, 'Efficiency and Technical Progress in Banking: Empirical Results for a Panel of German Banks’ (1996) 20 Journal of Banking and Finance 1003.

44 A Lozano-Vivas 'Profit Efficiency for Spanish Savings Banks' (1997) 98 European Journal of Operational Research 381.

45 M Dietsch and A Lozano-Vivas, 'How the Environment Determines Banking Efficiency: A Comparison between French and Spanish Industries' (2000) 24 Journal of Banking and Finance 985.

46 Y Altunbas, E P M Gardener, P Molyneux and B Moore, 'Efficiency in European Banking' (2001) 45 European Economic Review 1931.

47 J Bikker, 'Efficiency and Cost Differences across Countries in a Unified European Banking Market' (DNB Staff Reports No 87 De Nederlandsche Bank 2002).

48 J Maudos, J M Pastor, F Perez and J Quesada, 'Cost and Profit Efficiency in European Banks' (2002) 12 Journal of International Financial Markets, Institutions and Money 33.

49 P Schure, R Wagenvoort and D O'Brien, 'The Efficiency and the Conduct of European Banks: Developments after 1992' (2004) 13 Review of Financial Economics 371.

50 C Philip, 'Restoring Responsible Ownership - Ending the Ownerless Corporation and Controlling Executive Pay' (High Pay Centre September 2016); M J Cooper, G Huseyin and R P Raghavendra, 'Performance for Pay? The Relation between CEO Incentive Compensation and Future Stock Price Performance' (Unpublished Working Paper 2016); C Florackis and N Balafas, 'CEO Compensation and the Future Shareholder Returns: Evidence from the London Stock Exchange’ (2014) 27 Journal of Empirical Finance 97.

51 A Edmans in Department for Business, Energy and Industrial Strategy Committee, Corporate Governance (n 38).

52 Cooper et al (n50)

53 Philip (n 50).

54 C Florackis and N Balafas, 'CEO Compensation and the Future Shareholder Returns: Evidence from the London Stock Exchange' (2014) 27 Journal of Empirical Finance 97.

55 Edmans (n 51). 
Gregg et $\mathrm{al}^{56}$ analysed pay in the UK financial industry. They concluded that, whilst pay is high in financial organisations, the cash-plus-bonus pay-performance sensitivity of financial firms is not significantly higher compared to other industries. Their results showed that RBS had the highest total compensation in 2000 amongst the big four UK banks. By 2006, however, Barclays had the highest total compensation. Gregg et al are not convinced that the incentive structure in bankers' pay led to excessive risk-taking. One must note, however, that their results did not include equity incentive payments. In the UK, Sir David Walker ${ }^{57}$ criticised the role of non-equity incentive payments for not relating to long-term profitability. Perhaps this explains the focus on cash bonus in Gregg et al's study.

One then wonders why both the EU and the UK regulations (Shareholder Rights Directive (2007/36/EC); CRD IV; the Large and Medium-sized Companies and Groups (Accounts and Reports) (Amendment) Regulations 2013 and the Companies Act 2006) ask for disclosure of directors' remuneration if the above causal link is inconclusive to date. The authors submit three reasons why disclosure of directors' remuneration is important to good corporate governance. First, public trust in companies, especially banks, was eroded after the financial crisis of 2007-2009. Although the bashing of bankers and public outcry against bankers' remuneration have died down, the UK has one of the lowest trust levels in businesses in the Global 28 countries. Public trust in businesses in the UK was 45 per cent in 2017.58 As a comparison, the USA has a 58 per cent trust rate; France has a 50 per cent trust rate; Spain just pipped the UK with a 46 per cent trust rate; and Germany has a 43 per cent trust rate. ${ }^{59}$ The UK's trust rate has slipped 1 per cent compared to 2016. The general weak score can be explained by the public's dissatisfaction towards unfairness in executive remuneration and the tax arrangements of certain global companies. ${ }^{60}$ Additionally, recent corporate scandals at BHS, Sports Direct, Tesco, Rolls Royce and BAE Systems further weakened the public's trust in companies. The perception of corporate entities and the unfairness felt by the public are important, especially with the uncertainty of Brexit looming over workers. ${ }^{61}$ The truth is that the current political climate calls for social, responsible, stakeholder-led corporate governance in our society. Executive pay represents a very small proportion of expenditure for large companies (an estimated 0.6 per cent in the FTSE 100 companies). ${ }^{62}$ Corporate boards have the difficult task of balancing the value added by directors against public sentiment and the overall values of the company.

The second reason why disclosure of directors' remuneration matters is because London's appeal as an international financial hub faces stiff competition from other European financial centres, which enjoy the single passporting scheme. In total, there are nine passporting rights covering a range of financial services. Each passporting right derives from an EU directive or regulation. For example, a UK-based bank might use a CRD IV passport to provide corporate advisory services, lending or deposit services to a business in another EU state. Banks established in the EU or European Economic Area

56 P Gregg, S Jewell and I Tonks, 'Executive Pay and Performance: Did Bankers' Bonuses Cause the Crisis?' (2012) 12(1) International Review of Finance 89.

57 D Walker, A Review of Corporate Governance in UK Banks and Other Financial Industry Entities (Her Majesty's Stationery Office 2009).

58 Department for Business, Energy and Industrial Strategy Committee (n 38).

59 Ibid.

60 Edelman Trust Barometer 2017; CIPD Pulse Survey, December 2015.

61 Department for Business, Energy and Industrial Strategy Committee (n 38).

62 Edmans (n 51). 
(EEA) can establish branches in other EEA countries or provide financial services across the EEA without the need for further authorisation. Brexit transforms British banks into third-country banks. Brexit creates significant hurdles for banks in the EU and EEA when providing financial services in the EU since they lose the single passport advantages.

The alternative of obtaining a licence in each EU country is time-consuming and full of uncertainties. Not all EU countries provide licences. The scope of financial services operating under licences is limited and generally does not carry rights to onward crossborder trade from the country of licensing. ${ }^{63}$ The licence regime is subject to the caveat that Britain's regulatory regime is accepted by the EU as 'equivalent' to the EU standards. It can be argued that as long as Britain sustains its current standards under the current range of EU directives and regulations the 'equivalence' regime should apply. The reality is that there are three problems. First, a declaration of 'equivalence' can be revoked within 30 days. A declaration can be full or partial, as well as subject to a time limit. Besides, there is no defined period as to when the European Commission must provide a decision when assessing 'equivalence'. ${ }^{64}$ It took the European Commission four years to decide whether central clearing counterparties in the USA are equivalent. ${ }^{65}$ This uncertainty does not assist banks in planning for the long-term. Secondly, the 'equivalence' regime is not available in certain core banking activities, such as lending, deposit-taking, credit cards and payments. Finally, and most importantly, there is no agreed definition of 'equivalence' as yet. This is still subject to an agreement between the EU and Britain. Much depends on how much control the EU wishes to retain over Britain's regulatory developments and Britain's ability to break free of particularly onerous provisions. ${ }^{66}$

Finally, disclosure of directors' remuneration is important because shareholders' ability to express dissatisfaction or veto executive remuneration is weak in the UK. Shareholders of public companies in the UK have the right to vote on advisory resolutions about executive compensation. The say-on-pay vote was introduced by the UK government to increase 'accountability, transparency, and performance linkage' of executive pay. ${ }^{67}$ The advisory nature of such votes means that they are mainly symbolic. Indeed, Ferri and Maber ${ }^{68}$ demonstrated that the advisory resolutions on executive compensation had no effect on the level and growth of chief executive officer (CEO) pay. They examined the effect of the say-on-pay legislation in a large sample of UK firms by comparing the determinants of CEO pay before (2000-2002) and after (2003-2005) its introduction. Nevertheless, their research revealed that there was heightened sensitivity towards poor performance, particularly in companies which had very high remuneration. The Enterprise and Regulatory Reform Act 2013 introduced a binding vote on say-onpay to shareholders of quoted companies, but this is only available every three years in the UK. Using a large sample of binding and advisory votes in UK companies, Gregory-

63 British Bankers' Association 'What is “Passporting” and Why Does It Matter?' (BBA Brexit Brief \#3 2016) <www.bba.org.uk/wp-content/uploads/2016/12/webversion-BQB-3-1.pdf>.

64 Directorate-General for Internal Policies, 'Third-Country Equivalence in EU Banking Legislation' (Economic Governance Support Unit 2016) <www.europarl.europa.eu/RegData/etudes/BRIE/2016/587369/ IPOL_BRI(2016)587369_EN.pdf>.

65 Ibid.

66 J Ford, 'Financial Future after Brexit: Passporting v Equivalence' Financial Times (London, 12 January 2017) <www.ft.com/content/61221dd4-d8c4-11e6-944b-e7eb37a6aa8e>.

67 J Baird and P Stowasser, 'Executive Compensation Disclosure Requirements: The German, UK and US Approaches' (PracticalLaw.com, PLC Document 4-101-7960, 23 September 2002).

68 F Ferri and D Maber, 'Say on Pay Vote and CEO Compensation: Evidence from the UK' (2013) Review of Finance 527. 
Smith and $\mathrm{Mai}^{69}$ demonstrate that, even with a binding vote, it is unlikely that shareholder dissent will lead to a reduction in executive pay. The binding votes relate to the election of directors, both executive and non-executive, and the approval of long-term equitybased incentive schemes. The advisory vote relates to the annual advisory vote on the Directors' Remuneration Report. Gregory-Smith and Mai's results show that shareholders tend not to use binding votes to express disapproval of executive pay levels beyond the amounts merited by firm performance. Recent research by Correa et $\mathrm{al}^{70}$ refutes this. Their research on both binding and advisory say-on-pay laws in 12 countries shows that they are associated with lower executive pay levels - only advisory say-on-pay laws tighten the sensitivity of executive pay to firm performance. Gerner-Beuerle and Kirchmaier ${ }^{71}$ examine the impact of the UK's 2013 enhanced executive compensation disclosure rules on shareholders' say-on-pay votes. Using pay information disclosed by FTSE 100 firms, they found that shareholders focused on top-line salaries and seem to disregard the remaining information.

The binding say-on-pay vote to date is disappointing, although more time and research are required to provide more data, especially in the UK. The mixed results of say-on-pay on executive remuneration should not give rise to complete despondency for three reasons. First, the research by Ferri and $\mathrm{Maber}^{72}$ and Correa et $\mathrm{al}^{73}$ is encouraging because the advisory say-on-pay resolution has a positive impact on heightened sensitivity towards poor firm performance. Arguably, the evidence to date shows that most shareholders, apart from a few cases reported in the media, are not too unhappy with the level of executive pay. Rather, they are unhappy with the fact that directors should be paid high wages when the company is performing badly as a result of excessive risk-taking. Shareholders are understandably concerned that poor firm performance may lead to poor share returns. As such, high executive pay is not the main issue. The issues are more about the sensitivity of remuneration to company performance and a long-term pay structure. ${ }^{74}$

Secondly, it appears that say-on-pay has increased dialogues between companies and institutional investors. ${ }^{75}$ Large institutional investors will have more time and resources than small individual shareholders to monitor directors' remuneration. Finally, the new UK Public Register of publicising listed companies which have faced significant shareholder rebellions or have withdrawn resolutions in 2017 is intended to have a deterrent effect. Although 'significant' is not defined in the new directors' remuneration reporting regime, it is understood from the Directors' Reporting Remuneration Guidance 2016 that it means at least 20 per cent of votes cast against a resolution. ${ }^{76}$ Executive

69 I Gregory-Smith and B Main, 'Binding Votes on Executive Remuneration' (Working Paper 2014, Royal Economic Society Annual Conference).

70 R Correa and U Lel, 'Say on Pay Laws, Executive Compensation, Pay Slice, and Firm Valuation around the World' (International Finance Discussion Papers, Number 1084 Board of Governors of the Federal Reserve System, July 2013).

71 C Gerner-Beuerle and T Kirchmaier, 'Say on Pay: Do Shareholders Care?' (Discussion Paper no DP751, Financial Markets Group, London School of Economics and Political Science 2016).

72 Ferri and Maber (n 68).

73 Correa and Lel (n 70).

74 Edmans (n 51).

75 S Mason, A Medinets and D Palmon, 'Say-on-Pay: Is Anybody Listening?' (Annual Meeting Paper AAA 2012).

76 GC100 and Investor Group, Directors' Reporting Remuneration Guidance (2016) <https://uk.practicallaw.thomsonreuters.com/Link/Document/Blob/Ib127ccfd606f11e698dc8b09b4f043e $0 . p d f ?$ targetType $=$ PLC - multimedia\&originationContext $=$ document\&transitionType $=$ DocumentImage\&uniqueId=e9b9418d-73bd-4ec4-bd8d aceebae904d6\&contextData= (sc. Default) $\&$ firstPage $=$ true $\& b h c p=1>$. 
remuneration continues to be of interest for some shareholders. In 201738 per cent of resolutions related to annual remuneration reports or policies received significant votes against or were withdrawn. Apart from having a deterrent effect, this Public Register has the benefit of publicising how a company will respond to shareholders' concerns, thus increasing dialogues between the parties. Therefore, disclosure of information such as directors' remuneration should allow more transparency and better communication between companies and individual shareholders.

The evidence from 2017 shows that some shareholders do utilise the disclosed information for voting purposes. Nevertheless, one needs to monitor the future percentages of resolutions cast against annual remuneration to achieve a more accurate correlation between disclosure of executive remuneration and shareholder activism. The literature to date on shareholder activism casts doubt upon the efficacy of shareholder activism due to dispersed ownership in the UK. In 2014, overseas shareholders owned around 53.8 per cent of shares in the UK market. ${ }^{77}$ Dispersed ownership in the UK makes it difficult for individual investors to monitor companies. With Northern Rock, 144,000 of the 180,000 shareholders were found to be individual investors with small shareholdings. ${ }^{78}$ They lacked information or influence to monitor the board's performance. Coupled with short-termism of shareholders where the average period of share ownership is six months, ${ }^{79}$ shareholders face significant hurdles in taking an active part in monitoring directors. ${ }^{80}$ The implementation of the Stewardship Code in 2011 has increased shareholder participation by 68 per cent. ${ }^{81}$ Good voting turnout at annual general meetings (AGMs) does not necessarily lead to better engagement, since shareholders can purely make noise rather than constructive suggestions. Nonetheless, shareholder engagement in some UK companies, such as Aviva, AstraZeneca and WPP during the shareholder spring in 2012 shows that shareholders can play a positive role in corporate governance by challenging executive pay packages.

\subsubsection{OPPORTUNITIES FOR IMPROVEMENTS}

Disclosure of directors' remuneration is thus justified for good corporate governance in light of the above three factors. It is also necessary for Britain's economy in light of Brexit. The European Shareholder Rights Directive was adopted in April 2017 and Britain has until March 2019 to implement it. Such implementation is, of course, not compulsory due to Brexit. However, UK law already contains similar provisions. Say-on-pay legislation is incorporated in the Enterprise and Regulatory Reform Act 2013, the Large and Medium-sized Companies and Groups (Accounts and Reports) (Amendment) Regulations 2013 and the Companies Act 2006 (Strategic Report and Directors' Report) Regulations 2013. Essentially, quoted banks in the UK must have a binding say-on-pay resolution every three years and prescribe the requirements of the annual remuneration report and the minimum requirements of the directors' remuneration policy. The requirement of a company strategic report would provide shareholders with a holistic

77 Office for National Statistics, 'Ownership of UK Quoted Shares 2014' (Statistical bulletin 2015) <www.ons.gov.uk/economy/investmentspensionsandtrusts/bulletins/ownershipofukquotedshares/2015-09$02>$.

78 S Wen and J Zhao, 'Corporate Governance and the Financial Crisis: Did the Theories Stand the Test?' (2010) 25 Journal of International Banking and Financial Law 612-17.

79 Ibid.

80 A Lui, 'Cross-border Share Voting and Improving Voting Chain Deficiencies in the 21st Century' (2015) 6(1) International Journal of Corporate Governance 70-85.

81 R Sullivan, 'Investors Falling Short as Active Owners' Financial Times (London, 11 September). 
picture of the entire company's business model, strategy, development, performance and future prospects. Clause D.2.4 of the UK Corporate Governance Code invites shareholders to approve all long-term incentive schemes. Therefore, the direct impact of Brexit on disclosure of directors' pay is likely to be relatively minor.

There remains the important balance of attracting talent against a backdrop of calls for equality in society. The competitiveness and stability of Britain's financial industry are potentially affected by Brexit. As mentioned earlier, several American and Japanese banks are already moving or expanding their offices in Frankfurt in light of the loss of passporting rights. The increased competition might revive the argument that bankers need to be paid handsomely to retain talent in London. After all, how can banks in London attract talent when other European cities or international cities such as Hong Kong or Singapore are more appealing? Globalisation has without doubt ${ }^{82}$ increased the remuneration levels in the financial industry. Research by Gabaix and Augustin ${ }^{83}$ shows that between 1998-2003 American firms have grown in size due to globalisation. As a result of this growth, executive pay has also increased. High executive pay is argued to be justified because talent is more important in a globalised world ${ }^{84}$ and that the 'scalability' of CEOs is different to that of average employees. Kaplan's data-driven study supports the notion that the market for talent determines CEO salary. ${ }^{85}$ Their high salaries are justified because they increase the value of the companies they work for and they can be dismissed for poor performance. The average term for a CEO of a Standard and Poor's 500 company was six years in 2013 in comparison to eight years in 1998.86 Kaplan's view contrasts to the established view in corporate governance that executive pay is linked to company performance. ${ }^{87}$ In his opinion, the media tends to focus on the very high CEO pay and corporate scandals when the reality is not as sensational. Over the past 15 years, the median $\mathrm{CEO}$ pay has remained almost the same, but the mean $\mathrm{CEO}$ pay has decreased a great deal. CEO pay is therefore a reflection of supply and demand in the job market. Kaplan's results are supported by a UK study in 2016. A study into the executive pay of the CEOs of the FTSE 350 companies showed that the median pay was $f 1.9$ million in 2014. This was a rise of 82 per cent since 2011. At the same time, however, increase of invested capital was less than 1 per cent. ${ }^{88}$ Talent therefore drives executive pay.

One can argue that CEOs are only part of the bigger employee workforce in a company. Why treat CEOs in a special way? The answer is that there is evidence to show that CEOs matter in life and death. Two research papers of $2017^{89}$ support the argument that CEOs bring positive impact to companies in the long-term. Flammer and Pratima's

82 Edmans (n 51).

83 X Gabaix and L Augustin, 'Why has CEO Pay Increased So Much?' (2008) 123 Quarterly Journal of Economics 49.

84 Ibid.

85 V Sumo, 'Are CEOs Overpaid? The Case Against' (Chicago Booth Review, 26 September 2013) $<$ http://review.chicagobooth.edu/magazine/fall-2013/are-ceos-overpaid $>$.

86 Ibid.

87 B Holmström, 'Moral Hazard and Observability' (1979) 10 Bell Journal of Economics 74-91; M Jensen and K Murphy, 'Performance Pay and Top-Management Incentives' (1990) 98 Journal of Political Economy 22564.

88 R Davies, “Negligible” Link between Executive Pay and Firm's Performance, Says Study' The Guardian (London, 27 December 2016) <www.theguardian.com/business/2016/dec/27/negligible-link-betweenexecutive-pay-and-firms-performance-says-study $>$.

89 C Flammer and B Pratima, 'Does Long-Term Orientation Create Value? Evidence from a Regression Discontinuity' (2017) 38(9) Strategic Management Journal 1827; A Edmans, V Fang and A Lewellen, 'Equity Vesting and Investment' (2017) 30(7) Review of Financial Studies 222. 
study shows that there is a causal connection between giving long-term incentives for executives and improved company performance. In particular, their results reveal that shareholders' proposals of long-term incentives to executives improve both firm value and operating performance. Company strategies and stakeholder relationships are also improved as a result of long-term incentives. The second paper by Edmans et al reinforces the long-term structure of executive remuneration. Their use of 'vesting equity' (the amount of stock and options scheduled to vest in a given quarter) leads to CEOs cutting investment on long-term research and design projects and increasing shortterm earnings. Thus, they call for giving CEOs long-term incentives so that CEOs can implement long-term investments in research and design. CEOs contracts therefore affect real boardroom decisions.

Equally, a research paper of $2015^{90}$ shows that the departure and death of CEOs can have negative impacts on company value and performance. Besides, a CEO's decision to introduce the use of new technology will have a bigger effect in a large company than in a smaller one. ${ }^{91}$ The scalability of average employees is not entirely dependent on the company size. If the maximum number of cars an employee can fix is ten a day, it does not matter whether the company has 500 or 5000 cars. Rewards are thus higher for strategic and managerial talents than pure labour.

Nonetheless, the argument ignores the fact that poor strategies and management can have negative impacts on companies. The financial crisis of 2007-2009 has revealed several examples of poor strategies and management amongst certain UK banks. ${ }^{92}$ Therefore, sensitivity of executive pay and company performance matters. The advisory say-on-pay proves to be effective in heightening this sensitivity. Once there is such sensitivity, shareholders will hopefully scrutinise the CEO's actions in more detail. Transparency and disclosure are thus necessary to give shareholders access to information to make informed decisions. Disclosure of directors' remuneration can work both ways. From a company's perspective, more information available to shareholders potentially gives them more ammunition to rely upon at AGMs. Companies should see this not as an inconvenience, but as an opportunity to open dialogues and discuss and resolve matters with shareholders. Nevertheless, more disclosure provides transparency which in turn should increase public trust and investor confidence.

It is important to note, however, that the disclosure should contain accessible information which an average person can understand. Disclosing copious amounts of information is neither sensible nor useful. UK law requires a great deal of disclosure by listed companies, as seen above. In the modern era where digital technology is increasingly popular, it is proposed that such disclosure should be made on digital platforms or mobile applications for shareholders to access. In late 2015, Jimmy Choo worked with Equiniti to produce the first digital platform allowing shareholders to vote online at AGMs. The AGM mobile application was created as a native app (Android and iOS). The app works by directly integrating with the AGM software, which contains information of a physical AGM, such as attendance, voting and presentations. Through the app, shareholders can ask questions and vote on resolutions. Shareholders' identities and credentials are verified. They also need to enter a 'meeting ID' code before they can

\footnotetext{
90 A Falato, L Dan and T Milbourn, 'Which Skills Matter in the Market for CEOs? Evidence from Pay for CEO Credentials' (2015) 61 Management Science 2845.

91 Edmans (n 51).

92 Lui (n 3).
} 
vote online. Evidence from this Jimmy Choo online AGM reveals that shareholder engagement in 2016 was much better than for the physical AGM in 2015.93

Technology can thus improve shareholder engagement and there is interest from other companies in the development of online voting. ${ }^{94}$ Publishing dense strategic and directors' reports in a traditional format does not appeal to busy, time-poor investors, especially individual investors. However, useful information from such reports can also be fed into mobile applications and be presented in accessible format. Many mobile applications utilise artificial intelligence such as machine learning and predictive analysis to monitor and predict users' preferences according to their search histories. The authors submit that it would be useful to have a mobile application that can send personalised, tailored disclosure of company information, such as directors' remuneration, strategy and company performance, to shareholders. Keywords, summaries and links to remuneration, strategy and performance should be accessible through the mobile app. Paper copies of reports should still be available for shareholders, but digital technology should allow shareholders to access such information at their convenience and be able to enjoy a more tailored format. By remembering and storing a shareholder's preferences and search histories, algorithms can personalise the reports.

Ultimately, directors' remuneration should be decided by company remuneration committees. It is not for governments to decide the level of executive pay. Regulation is often reactive, driven by political will rather than shareholders' wishes. The American experience in regulating executive pay for 80 years has taught us that a web of remuneration schemes was developed as a result of regulatory arbitrage. In brief, their attempt to regulate pay was unsuccessful and produced counterproductive payment schemes. It is right, however, for a government to increase stakeholders' influence on executive pay. The Conservative government has not adopted the call for an annual, binding say-on-pay vote. However, it will introduce secondary legislation to incorporate more disclosure requirements which will require listed companies to publish their annual pay ratios between CEOs and employees. ${ }^{95}$ It also requires companies to explain in their strategic reports how directors comply with s 172 Companies Act 2006 and have regard to employees' interests. The government has asked the FRC to revise the UK Corporate Governance Code to be more specific about the steps that listed companies should take when they encounter significant shareholder opposition (likely to be 20 per cent or more) to remuneration and other resolutions. The tone of the government's response suggests that it will rely mainly on the 'comply or explain' style of the UK Corporate Governance Code. It is prepared, however, to be more prescriptive and legislate if the 'comply or explain' style fails to deliver. It is hoped that listed companies will comply with the new disclosure requirements as legislation can create its own problems. Much depends on the government's ability not to bow down to city lobbyists. ${ }^{96}$ Finally, even if the disclosure requirements lead to a reduction of executive pay through a say-on-pay vote, they only cure one weakness of the bigger corporate governance framework in the UK and it might

93 S Ellen, 'AGM Innovation' (ICSA The Governance Institute 2016) <www.icsa.org.uk/ knowledge/governance-and-compliance/analysis/september-2016-agm-innovation>.

94 Ibid.

95 Department for Business, Energy and Industrial Strategy, 'Corporate Governance Reform: The Government Response to the Green Paper Consultation' (2017) <www.gov.uk/government/uploads/ system/uploads/attachment_data/file/640631/corporate-governance-reform-government-response.pdf $>$.

96 J Stone and J Watts, 'Brexit: Big Business and Banks are Dominating Formation of Brexit Warns Report' The Independent (London, 26 August 2017) <www.independent.co.uk/news/uk/politics/brexit-talks-negotiationsdavid-davis-corporate-banks-eu-lobbying-brussels-a7913131.html $>$. 
not have a lasting effect. The success of the say-on-pay vote depends largely on shareholder activism. The fact is that overseas investors own 53.8 per cent of shares in UK listed companies. ${ }^{97}$ Shareholder activism on a yearly basis, voting on executive remuneration in a dispersed ownership jurisdiction, is thus difficult. ${ }^{98}$

\section{Conclusion}

Legally, Brexit will have a limited impact on UK law on executive remuneration. This article looked at three specific areas of executive remuneration, namely: the bonus cap; the clawback of pay; and the level of disclosure required by shareholders regarding details of directors' remuneration and the extent to which shareholder approval is needed. A great deal of the law set out in EU directives and regulations is already implemented in UK legislation. Besides, public sentiment for equality in society and the general anxiety over the Brexit negotiations will probably maintain the status quo: certainly, in the foreseeable future until the outcomes of future trade deals are clearer. However, people's memories fade with time. Britain needs to compete with other important financial centres globally in a post-Brexit era. Competition is fierce and talent has become more important. Incentives are required to attract talent to London's financial sector. High executive pay is justified as CEOs' scalability is different to that of the average employee. Most shareholders accept the level of executive pay, contrasted with the public's anger towards unfairness in compensation and distrust of big companies. Sensitivity of executive compensation and company performance is heightened with advisory say-on-pay votes. Continuation of this should be pursued as it should encourage shareholders to engage more with companies, scrutinising CEOs' actions and decisions, leading to better corporate governance. Disclosure of directors' remuneration is required to provide more voice to shareholders. An opportunity arises with digital technology such as mobile applications. They may create better access to such information and personalised services. European legislation in corporate governance has addressed the issue of executive remuneration. Britain now has the choice to retain the status quo, or repeal part or all of the law on executive remuneration. In practice, much depends on political will and market forces. Brexit brings both challenges and opportunities to Britain. It is now up to the government and companies working together for a new Britain after Brexit.

97 Office for National Statistics (n 77).

98 For a discussion on how to improve shareholder engagement, see A Lui, 'Cross-border Voting Chains and the Case for Improving the Quality of Shareholder Engagement' (2015) 6 International Journal of Corporate Governance 70 . 
